\title{
Soil thermal buffer and regeneration niche may favour calcareous fen resilience to climate change
}

\author{
Eduardo Fernández-Pascual ${ }^{1,4}$, Borja Jiménez-Alfaro², Michal Hájek ${ }^{2,3}$, Tomás E. Díaz ${ }^{4}$, Hugh W. Pritchard ${ }^{1}$ \\ ${ }^{1}$ Comparative Plant and Fungal Biology, Royal Botanic Gardens, Kew, Wellcome Trust Millennium Building, Wakehurst \\ Place, Ardingly, West Sussex RH17 6TN, UK ; ${ }^{2}$ Department of Botany and Zoology, Masaryk University, Kotlářská 267/2, \\ 61137 Brno, Czech Republic; ${ }^{3}$ Department of Vegetation Ecology, Institute of Botany, Academy of Sciences of the Czech \\ Republic, Lidická 25/27, 65720 Brno, Czech Republic; ${ }^{4}$ Jardín Botánico Atlántico, Universidad de Oviedo, Avda. del \\ Jardín Botánico 2230, 33394 Gijón/Xixón, Spain
}

Corresponding author: Eduardo Fernández-Pascual; Telephone: +44 (0)1444894184; Fax: +44 (0)1444 894110; email: e.fernandezpascual@kew.org

This is a pre-copyedited, author-produced PDF of an article accepted for publication in Folia Geobotanica following peer review. The version of record (Fernández-Pascual, E., Jiménez-Alfaro, B., Hájek, M., Díaz, T. E., \& Pritchard, H. W. (2015). Soil thermal buffer and regeneration niche may favour calcareous fen resilience to climate change. Folia Geobotanica 50, 293-301) is available online at: http://dx.doi.org/10.1007/s12224-015-9223-y.

\begin{abstract}
Calcareous fens are azonal habitats permanently saturated by groundwater. This is expected to have a buffer effect on soil temperature, alleviating climate changes and allowing plant communities to occupy diverse climatic regions. We analysed the extent of such buffering and its relation with a relevant plant trait, the seed germination niche breadth, along altitudinal gradients in fens of the Cantabrian Mountains (Spain) and the Western Carpathians (Slovakia). In each fen we recorded soil temperature for several years and compared it with WorldClim predictions for air temperature. We also collected seeds from five Cyperaceae fen specialists to evaluate the influence of soil temperature on germination. Although soil temperatures and WorldClim were strongly correlated, their absolute values differed substantially, showing a narrower thermal amplitude and warmer minimum winter temperature in the soil. The greatest differences in soil temperature and germination niche breadth were those between mountain regions. Narrower germination niches correlated with the colder Slovakian winter. Our results suggest that the soil thermal buffer allows species to prevent frost temperatures in winter, but also high summer temperatures in warm regions, explaining their wide distribution ranges. The warm regeneration niche does not match the cooler soils, but shows variability and potential for adaptation. While this findings support resilience to climate warming, changes in precipitation rather than temperature seem to be the main threat for fen persistence.
\end{abstract}

Keywords: Azonal plant communities; Cyperaceae; microclimate; mire ecology; plant-climate interactions; seed germination niche breadth

\section{Introduction}

Climate change is affecting plant communities worldwide, provoking alterations of recruitment (Hoyle et al. 2013), loss of suitable habitats (Dullinger et al. 2012), upward range shifts (Pauli et al. 2012) and vegetation changes (Gottfried et al. 2012). Most evaluations have been conducted on zonal vegetation types such as forests (Felton et al. 2009), probably because they are mainly influenced by macro-ecological factors. However, much less is known about the responses of azonal vegetation types, i.e. those that depend only secondarily on climate, their occurrence being driven by local edaphic conditions (Breckle 2002).

A typical example of azonal vegetation are calcareous fens (also called alkaline fens, small-sedge fens or calcareous spring fens; hereafter shortened to fens) (Hájek et al. 2006). Fens are priority habitats for conservation that harbour a high number of endangered species (Bergamini et al. 2009). Fen formation and maintenance are governed by the hydrological regime of hard-water springs, which support highly-adapted flora in spatially reduced areas (Grootjans et al. 2006, Jiménez-Alfaro et al. 2013). This dependence on fastidious conditions of climate and hydrogeology makes fens potentially vulnerable to environmental changes (Parish et al. 2008). However, most climate change assessments on these environments rely on spatial models of air temperature (Essl et al. 2012), making an in situ investigation of fen thermal conditions much needed.

In Europe, fens are distributed from the Iberian Peninsula to Fennoscandia and from low valleys to the alpine belt, but nonetheless the constituent and dominant species remain relatively homogeneous (Jiménez-Alfaro et al. 2014). An apparent climatic resilience of fen species is further suggested by the persistence of relicts in their distribution limits (Amon et al. 2002, Topić and Stančić 2006, Hájek et al. 2009, Jiménez-Alfaro et al. 2012). A possible cause for this climatic resilience may be the buffer effect of groundwater on soil temperature, reducing the expected differences of the realized niche in diverse climatic regions (Ellenberg 1988). Indeed, the cool waters from underground aquifers that saturate fens 
are expected to keep temperatures warmer during cold periods and vice versa (Ellenberg 1988, Geiger et al. 2009). As root-zone temperature is known to be a major determinant of plant ecophysiology (Körner and Paulsen 2004), this buffer effect might allow fen species to regenerate and live along a wider range of air temperatures than they could otherwise. However, this hypothetical buffer effect appears not to have been studied directly and its actual field characteristics are not known.

The buffer effect can potentially affect all relevant ecophysiological plant processes, beginning with regeneration by seed. Germination timing is essentially governed by environmental temperature (Bewley et al. 2013) and is highly sensitive to climate warming (Walck et al. 2011, Orrù et al. 2012). Variability in germination traits allows plants to find suitable habitats amidst environmental changes, supporting their persistence under global change (Cochrane et al. 2015). This variability can be addressed by the germination niche breadth, a relevant plant trait that defines the amplitude of external conditions that elicit germination (Marques et al. 2014). Broad germination niches permit broader ecogeographical ranges and are favoured by fecundity selection, but also increase the risk of seeds germinating into suboptimal or lethal establishment environments (Donohue et al. 2010). However, it is unclear to what extent the warm temperatures that elicit germination in many fen species (Schütz 2000) actually match the field thermal range (Fernández-Pascual et al. 2013). A correct evaluation of the overlapping between soil temperature and germination niche is therefore necessary to assess the sensitivity of fen communities to climate change.

In this work we analyse soil temperatures and the seed germination niche in fens from two contrasting regions of their European distribution. We measure in situ soil temperatures and perform germination experiments from different sites along regional altitudinal gradients in Central Europe and in the Iberian Peninsula. Our main aims are to (1) quantify soil thermal buffering as compared with temperatures predicted by climatic models, (2) evaluate the match between soil temperatures and the germination niche of fen specialists, and (3) discuss the implications of climate buffering and the germination niche breath for the assessment of climate change.

\section{Methods}

\section{Study system and temperature data}

This study took place in the Cantabrian Mountains (Spain) and the Western Carpathians (Slovakia). Within each region, we selected three sites covering the local altitudinal gradients of fen vegetation (Table 1). In June 2010 we placed temperature dataloggers (M-Log5W, GeoPrecision, Ettlingen, Germany) in each site, buried 5 $\mathrm{cm}$ in the soil in a flat and central area. In this ecosystem, it is at this depth that true soil begins to develop, under the porous upper layers made up of live mosses. After three years of measurements, we downloaded the data for further analysis. For reasons beyond our control, the datalogger at the middle-altitude Slovakian site vanished during the second year and therefore only one year of measurements could be considered for this site.

We compared our soil temperatures with those more frequently used in climate change studies, the WorldClim model averaged for the last 50 years (Hijmans et al. 2005). From both data sources we calculated several parameters: (1) monthly averages of daily means; (2) monthly averages of daily maxima, hereafter day temperatures; (3) monthly averages of daily minima, hereafter night temperatures; (4) temperature extremes in winter (Wmin, December-February average of the daily minima) and (5) summer (Smax, JuneAugust average of the daily maxima); (6) number of months with mean temperatures under $1{ }^{\circ} \mathrm{C}$; and (7) number of months with minimum temperatures under zero. We compared soil and WorldClim parameters with Linear Mixed Models (LMM, for parameters 1 to 5) and Generalized Linear Mixed Models with binomial distribution and logit link function (for variables 6 and $7)$, considering in all cases country and altitude nested within country as random factors.

\section{Germination experiments}

Detecting across-species patterns in the germination niche requires an ecologically and taxonomically homogeneous study group (Luna and Moreno 2012). Here we chose Cyperaceae Juss., the dominant plant family in fens, whose members usually show type 2 non deep physiological dormancy (Baskin and Baskin 2004). This means that freshly dispersed seeds can germinate only at warm temperatures (c. $25^{\circ} \mathrm{C}$ ), and acquire the capacity to germinate at cooler temperatures $\left(<15^{\circ} \mathrm{C}\right)$ as they lose dormancy (Schütz 2000, Fernández-Pascual et al. 2013). During the 2011 dispersal season (JulySeptember) we collected 'seeds' (achenes or utricles) from five Cyperaceae commonly found in the study sites: Blysmus compressus (L.) Panz. ex Link, Carex davalliana Sm., Carex echinata Murray, Carex lepidocarpa Tausch and Eriophorum latifolium Hoppe. Seeds stayed three weeks in our laboratory (c. $22^{\circ} \mathrm{C}, 50$ $\% \mathrm{RH})$ before undergoing germination experiments to characterize the germination niche breadth of each collection.

For each collection and treatment, we sowed 25 seeds in each of four Petri dishes (1\% agar-water), sealed with Parafilm to prevent desiccation. Experimental factors were two: (1) pre-treatment (fresh = no pre-treatment; cold-stratified $=12$ weeks on $1 \%$ agar-water at $3{ }^{\circ} \mathrm{C}$ in darkness, simulating overwintering); and (2) germination temperature: $30 / 20^{\circ} \mathrm{C}$ (unusual heat), $22 / 12^{\circ} \mathrm{C}$ (summer conditions) and $14 / 4{ }^{\circ} \mathrm{C}$ (spring-autumn conditions) (Fernández-Pascual et al. 2013b). Temperatures were programmed on growth chambers (Grow-S 360, Ing. Climas, Barcelona, Spain) operating on $12 / 12 \mathrm{~h}$ photoperiods, with the warmest temperature coupled to the light interval $(20 \mu \mathrm{mol} \mathrm{m}-2 \mathrm{~s}-1$ provided by six Philips TLD30W/54-765 cool fluorescent tubes). We 
scored seed germination (as $2 \mathrm{~mm}$ radicle emergence) weekly, and after four weeks we opened the seeds remaining in the test with a scalpel, classifying them as apparently viable non-germinated, empty and infected. Empty and infected seeds were excluded from further analyses.

We estimated the germination niche breadth of each collection as Pielou's evenness index (Brändle et al. 2003, Cerabolini et al. 2003, Luna and Moreno 2012), using the average percentage germination at each of the six experimental treatments. This index takes values from zero (high sensitivity to one treatment, narrower germination niche) to one (germination evenly distributed across treatments, broader germination niche). Germination niche breadth had a normal distribution, thus we analysed the variability in germination niche breadth among species, regions and sites using ANOVA. Subsequently, we analysed the correlation between germination niche breadth and soil temperature by fitting LMMs to germination niche breadth data with Wmin and Smax as fixed predictors and species as a random factor. We chose Wmin and Smax to represent the temperature limits or more extreme temperatures at each site. We also plotted the relationship between the significant predictors and germination niche breadth by linear regression, using the residuals of a LMM computed with no fixed effect and only the species as a random factor to rule out the potential effect of between-species variation. Wmin and Smax were not significantly correlated $(r=0.075, \mathrm{p}=$ $0.888, \mathrm{n}=6$ ) and the model residuals were not spatially autocorrelated ( $p>0.05$, Moran's I test computed using ArcGis v9.3, Esri, Redlands, USA). We performed the statistical analyses with SPSS (v21.0, IBM, Armonk, USA).

\section{Results}

\section{Temperature}

Soil temperatures recorded at the different sites by the dataloggers were significantly correlated to air temperatures predicted by the WorldClim model (Fig. 1), considering mean $(\mathrm{r} 2=0.927, \mathrm{p}<0.001, \mathrm{n}=6)$, day $(\mathrm{r} 2$ $=0.928, \mathrm{p}<0.001, \mathrm{n}=6)$ and night $(\mathrm{r} 2=0.912, \mathrm{p}<0.001$, $\mathrm{n}=6)$ values. Nonetheless, absolute values were different. As a whole, WorldClim-predicted mean temperatures were slightly colder than observed temperatures (7.1 vs. $9.2{ }^{\circ} \mathrm{C}, \mathrm{F}(1,10)=16.001, \mathrm{p}=$ $0.003)$, although there was seasonal variation as differences were significant in winter $\left(-0.5\right.$ vs. $3.8^{\circ} \mathrm{C}, \mathrm{F}$ $(1,10)=18.882, \mathrm{p}=0.001)$ but not in summer $(14.8 \mathrm{vs}$. $\left.15.7{ }^{\circ} \mathrm{C}, \mathrm{F}(1,10)=1.156, \mathrm{p}=0.308\right)$. A remarkable difference was found in the temperature limits in both seasons (Table 1); WorldClim predicting warmer maxima in summer $\left(21.4\right.$ vs. $18.0^{\circ} \mathrm{C}, \mathrm{F}(1,10)=9.137, \mathrm{p}$ $=0.013)$ and colder minima in winter $\left(-4.1\right.$ vs. $3.4{ }^{\circ} \mathrm{C}, \mathrm{F}$ $(1,10)=69.944, p<0.001)$. Differences were also marked in night temperatures, predicted to be much colder in WorldClim $\left(2.3\right.$ vs. $8.0^{\circ} \mathrm{C}, \mathrm{F}(1,10)=225.237$, $\mathrm{p}<0.001)$, while day temperatures were not significantly different (12.0 vs. $\left.10.9^{\circ} \mathrm{C}, \mathrm{F}(1,10)=2.827, \mathrm{p}=0.124\right)$. Accordingly, WorldClim predicted a higher number of months with mean temperatures under $1^{\circ} \mathrm{C}(2.8$ vs. 0.8 , $\mathrm{F}(1,10)=7.213, \mathrm{p}=0.023)$ and with negative minimum temperatures $(4.7$ vs. $0.2, \mathrm{~F}(1,10)=13.936, \mathrm{p}=0.004)$, suggesting more common freezing events.

\section{Germination}

The germination of the five species (Table 2) shared a common pattern: fresh germination occurred only at warm temperatures; and germination was possible at cooler temperatures after stratification. All seed collections germinated at $30 / 20^{\circ} \mathrm{C}$ without previous cold stratification, although percentages were usually low. Fresh germination also occurred at $22 / 12{ }^{\circ} \mathrm{C}$ in $\mathrm{B}$. compressus, E. latifolium and especially C. echinata. Cold stratification increased germination in all the species at $30 / 20{ }^{\circ} \mathrm{C}$ and $22 / 12{ }^{\circ} \mathrm{C}$, and also at $14 / 4{ }^{\circ} \mathrm{C}$ in C. davalliana, C. echinata and E. latifolium.

Germination niche breadth (Fig. 2) was significantly different among species $(\mathrm{F}(4,11)=31.987, \mathrm{p}<0.001)$. From narrower to broader niches it averaged (mean $\pm \mathrm{SE}$ ) $0.43 \pm 0.06$ in C. lepidocarpa, $0.56 \pm 0.04$ in $\mathrm{B}$. compressus, $0.68 \pm 0.02$ in C. davalliana, $0.77 \pm 0.03$ in E. latifolium and $0.87 \pm 0.01$ in $\mathrm{C}$. echinata. Germination niche breadth was significantly broader in Spanish collections $(\mathrm{F}(1,11)=9.153, \mathrm{p}=0.009)$ but showed no significant differences among sites nested within regions $(\mathrm{F}(4,11)=1.990, \mathrm{p}=0.148)$. Regarding site temperatures, germination niche breadth was significantly correlated to the winter minima at each site ( $F(1,18)=8.932, p=0.008)$ but not to the summer maxima $(F(1,18)=0.227, p=0.640)$. After ruling out the differences among species, a significant positive correlation existed between the germination niche breadth residuals of the collections and the winter minima at each site (Fig. 3).

\section{Discussion}

\section{Soil thermal buffer in fens}

This study demonstrates that the temperature of fen soils is in general less variable and less extreme than forecast by standard models of air temperature, thus suggesting a buffer effect of groundwater systems. Nevertheless, the magnitude of this effect varies temporally. During day and in summer soils seem relatively sensitive to air temperature, being less water-saturated as a consequence of warmer air and solar radiation, which likely reduces the buffer effect. In contrast, during night and in winter soil temperatures never get as cold as would be expected, and so the buffer effect seems stronger over the cold end of the thermal gradient. This suggests that the main consequence of the buffer is to reduce the likelihood of soils becoming extremely cold, allowing fen species to occupy sites with lower air temperatures than they could otherwise. This effect has been observed in Western Siberia, where fens are especially rich in relict thermophilous species, contrasting with rain-fed bogs which host relict species from colder periods (Lapshina 
2004). Similarly in Slovakia, thermal springs acted as refuges for warm-demanding wetland species during the Quaternary (Hájková et al. 2013); and human-favoured mountain fens gave shelter to lowland wetland specialists once lowland fens were destroyed by human colonization (Jamrichová et al. 2014). If night and winter cold extremes are indeed the limiting factors masked by soil water buffering, then the direct risks of climate warming are lessened. However, confirming this hypothesis will require a detailed study of the potential thermophilous nature of fen species compared to other ecosystems.

We also found that soil temperature varies among altitudes and regions, but this variation is not as pronounced as predicted by WorldClim air temperatures, again supporting a buffer effect. Soils are generally colder in Slovakia and at higher altitudes, following the known gradients of latitude and altitude (Breckle 2002); but again different patterns can be described in winter and in summer. In winter, Slovakian soils are much colder and temperatures close to zero indicate an influence of snow cover that is not felt in Spain, but altitudinal differences are relatively small. In summer, soil temperatures are relatively similar in both regions and differences seem in this case more driven by altitude, with a sharp drop in the higher sites. This suggests a cooling effect in the Iberian fens, which are subjected to warmer air temperatures than Slovakian ones. While a dry soil is expected to experience high temperature maxima as a consequence of solar radiation in the central parts of the day (Geiger et al. 2009), this cooling effect seems to prevent extreme warm temperatures. This effect is especially noticeable during the summer in the Spanish fens, explaining the persistence of cold-adapted species in fens of relatively warm regions such as the Cantabrian Mountains (Jiménez-Alfaro et al. 2012). This supports the idea that alpine-boreal relict species at warm regions also benefit from cooling regulation during summer (Ellenberg 1988).

We note that further interpretation of the fen soil thermal buffering will require comparative studies with other soils and with air temperatures measured in situ. WorldClim predicts air temperature, and a certain degree of buffering is expected in any kind of soil (Geiger et al. 2009). In our study system, soils under predicted air temperatures would suffer frequent episodes of freezing, which rarely occur in the recorded data. Freezing can be prevented by snow cover, and most of the sites are certainly covered by snow during the winter, but still their soil temperatures are higher than the stable $0-1{ }^{\circ} \mathrm{C}$ that is expected under snow. Especially in Spain, of the 1095 days of records, temperatures suggesting snow cover were only registered during 15 days, and only in the middle-altitude site. These patterns are strikingly different from those commonly found in other mountain soils (Körner 2003). In moist soils, when the temperature drops to zero the transition of water to ice releases latent heat that stops further cooling until all groundwater freezes, a process called the zero-curtain effect (Outcalt et al. 1990, McKenzie et al. 2007). In fens, the continuous input of groundwater might greatly prolong this effect, determining fundamental differences with other moist soils with a limited groundwater supply, e.g. blanket bogs. Such ecosystem-specific variation in environmental perturbation or stability likely has a profound effect on the autecology of bog and fen species, and should determine key differences in the response to environmental changes such as climate warming.

\section{Germination niche and soil temperature}

The germination patterns in response to temperature are homogeneous in all the studied species, suggesting a general pre-adaptation of fen species to the habitat. All species had their optimal germination temperature around $25{ }^{\circ} \mathrm{C}$, as is expected in wetland Cyperaceae (Schütz 2000, Fernández-Pascual et al. 2013). This temperature is strikingly out of the field thermal range, and was never registered during three years of measures. In normal conditions, the study species are thus expected to germinate slowly as they lose dormancy and their germination temperature range broadens towards lower values. Quick germination at $25^{\circ} \mathrm{C}$ could only occur in extraordinary situations when the soil dries. Wetland Cyperaceae regeneration seems to be defined by these fast gap-detecting strategies, including pseudovivipary (Leck and Schütz 2005) and the response to diurnallyalternating temperatures (Fernández-Pascual et al. 2015). Although related species are expected to share similar germination strategies due to phylogenetic constrains (Carta et al. 2014), we found subtle differences that seem to be related to different ecological preferences. The response to warm temperatures appears to be relatively stronger in B. compressus and C. lepidocarpa, species of low-productive and rather open vegetation. Especially B. compressus colonizes disturbed fens and gaps produced by cattle trampling (Coldea et al. 1997, Jamrichová et al. 2014). Both these species are typical of fens from warmer regions of south-eastern Europe, which are usually managed by grazing (Hájek et al. 2008). Conversely, an ability to germinate at $14 / 4{ }^{\circ} \mathrm{C}$ after stratification is shown by $\mathrm{C}$. davalliana and $\mathrm{C}$. echinata, species that dominate more established stages where dry gaps are rarer. Contrary to the two former species, C. davalliana and $\mathrm{C}$. echinata can reach high abundances in ungrazed and rather productive wet Calthion grasslands (Klimesova et al. 2011).

In general terms, the germination niche of the study species is broad and responds to an ample thermal range. Interestingly, the broadest germination niche is shown by a species with the broader niche within the mire conductivity gradient, Carex echinata, thus agreeing with what has been called the regeneration niche hypothesis (Marques et al. 2014). We also found that within-species variability in germination niche breadth correlates with regional differences in the winter minimum temperatures. Environmental variation, especially when it is temporal (e.g. unfavourable weather) rather than spatial (e.g. patchy landscapes), makes narrower niches adaptive because postponing germination may increase the chance of finding adequate environments (Donohue 
et al. 2010). Restricted germination through seed dormancy has already been identified as a bet-hedging strategy conferring fitness advantages in variable environments (Gremer et al. 2012), and it seems that germination niche breadth further attunes germination timing to environmental variability. This broad nature of the germination niche, coupled with its variability, is expected to contribute to the persistence of fen species under climate warming (Walck et al. 2011, Cochrane et al. 2015). However, this variability seems to operate only between regions. Within regions, altitudinal differences of about $1000 \mathrm{~m}$ were not significant, contrasting with the altitudinal variation that has been reported for other traits such as seed/fruit weight or seed dormancy (Cochrane et al. 2015). This concurs with the observation that, in this habitat, the buffer effect reduces altitudinal differences in winter temperatures, precisely those related to germination niche breadth.

\section{Conclusions}

This study explored two mechanisms that might play a role in the response of fen communities to climate change; the buffer effect of soil water and the thermal niche for seed germination. Overall, our results point to the potential of fen species for climatic resilience, explaining their persistence in regions with contrasting climates (Topić and Stančić 2006, Hájek et al. 2009, Hájek et al. 2011, Jiménez-Alfaro et al. 2012). The soil thermal effect allows fen species to prevent frost temperatures in winter, but also high summer temperatures in warm regions (Ellenberg 1988), explaining the wide distribution ranges of the fen species in Europe (Jiménez-Alfaro et al. 2014). Our study also shows a latitudinal correlation between germination niche breadth and winter temperatures. Although a similar correlation has been established for seed dormancy (Carta et al. 2015), to our knowledge this is the first time that it has been explicitly confirmed with germination niche breadth, a more comprehensive concept that includes the spreading of germination over a wider or narrower range of conditions. Germination niche breadth is known to correlate with species distribution and abundance (Brändle et al. 2003; Luna and Moreno 2010), and our study further highlights its essential role in plant ecology.

Finally, we must note that wetlands primarily depend on the quantity and quality of their water supply (Erwin 2009), and fens may be extremely sensitive to the predicted decreases in precipitation (Essl et al. 2012), which could compromise the buffer effect. In fact, European fens are restricted to non-Mediterranean regions (Jiménez-Alfaro et al. 2014) and threatened in transitional climatic regions (Topić and Stančić 2006). Thus, a "Mediterranean-ization" reducing water supply in extremely dry summers might be the main threat for the persistence of fen species. Considering secondary climatic variables, local edaphic conditions and species regeneration traits is thus fundamental for understanding plant responses to climate change in azonal vegetation types.

\section{Acknowledgements}

We wish to thank E. Aguado, R. Carro, D. Cooper, E. Correia, K. Devánová, C. García, P. Hájková and Z. Plesková for contributing to field work; L. Carlón for taking part in the discussion of climatic data; and several anonymous reviewers for improving the manuscript. The Masaryk University of Brno provided institutional support. E.F.P. was supported by the Government of Asturias (Grant BP09-107, Programa de Ayudas Predoctorales 'Severo Ochoa', Plan de Ciencia, Tecnología e Innovación del Principado de Asturias) and the FP7-Marie-Curie-COFUND programme of the European Commission (Grant 'Clarín' ACA14-19); B.J.A. by the project 'Employment of Best Young Scientists for International Cooperation Empowerment' (CZ.1.07/2.3.00/30.0037) co-financed by the European Social Fund and the state budget of the Czech Republic; M.H. by the Academy of Sciences of the Czech Republic (RVO 67985939). Permission for field work was granted by the governments of Asturias and Castile-Leon. Experiments complied with the laws of the countries where they were conducted.

\section{References}

Amon J, Thompson C, Carpenter Q, Miner J (2002) Temperate zone fens of the glaciated Midwestern USA. Wetlands 22: 301-317.

Baskin JM, Baskin CC (2004) A classification system for seed dormancy. Seed Sci Res 14: 1-16.

Bergamini A, Peintinger M, Fakheran S, Moradi H, Schmid B, Joshi J (2009) Loss of habitat specialists despite conservation management in fen remnants 1995-2006. Perspect Plant Ecol Evol Syst 11: 65-79.

Bewley JD, Bradford K, Hilhorst H, Nonogaki H (2013) Seeds: Physiology of Development, Germination and Dormancy. 3rd Edition. Springer, Berlin - Heidelberg - New York.

Brändle M, Stadler J, Klotz S, Brandl R (2003) Distributional range size of weedy plant species is correlated to germination patterns. Ecology 84: 136-144.

Breckle S-W (2002) Walter's Vegetation of the Earth: The Ecological Systems of the Geo-biosphere. Springer, Berlin Heidelberg New York.

Carta A, Probert R, Moretti M, Peruzzi L, Bedini G (2014) Seed dormancy and germination in three Crocus ser. Verni species (Iridaceae): implications for evolution of dormancy within the genus. Plant Biol 16: 1065-1074.

Carta A, Probert R, Puglia G, Peruzzi L, Bedini G (2015) Local climate explains degree of seed dormancy in Hypericum elodes L.(Hypericaceae). Plant Biol, in press.

Cerabolini B, Ceriani RM, Caccianiga M, De Andreis R, Raimondi B (2003) Seed size, shape and persistence in soil: a test on Italian flora from Alps to Mediterranean coasts. Seed Sci Res 13: 75-85.

Cochrane A, Yates CJ, Hoyle GL, Nicotra AB (2015) Will amongpopulation variation in seed traits improve the chance of species persistence under climate change? Global Ecol Biogeogr 24: 12 24.

Coldea G, Vasile S, Aurel P, Nicolae S (1997) Les associations végétales de Roumanie. Presses Universitaires, Cluj.

Donohue K, de Casas RR, Burghardt L, Kovach K, Willis CG (2010) Germination, postgermination adaptation, and species ecological ranges. In: Futuyma DJ, Shafer HB, Simberloff D, eds. Annual Review of Ecology, Evolution, and Systematics 41. Annual Reviews, Palo Alto, p 293-319.

Dullinger S, Gattringer A, Thuiller W, Moser D, Zimmermann NE, Guisan A et al (2012) Extinction debt of high-mountain plants under twenty-first-century climate change. Nature Climate Change 2: 619-622.

Ellenberg H (1988) Spring areas and adjacent swamps. Vegetation Ecology of Central Europe, 4th edition. Cambridge University Press, Cambridge, p 313. 
Erwin K (2009) Wetlands and global climate change: the role of wetland restoration in a changing world. Wetlands Ecol Manage 17: 71-84.

Essl F, Dullinger S, Moser D, Rabitsch W, Kleinbauer I (2012) Vulnerability of mires under climate change: implications for nature conservation and climate change adaptation. Biodivers Conserv 21: 655-669.

Felton A, Fischer J, Lindenmayer D, Montague-Drake R, Lowe A, Saunders D et al (2009) Climate change, conservation and management: an assessment of the peer-reviewed scientific journal literature. Biodivers Conserv 18: 2243-2253.

Fernández-Pascual E, Jiménez-Alfaro B, Díaz TE (2013) The temperature dimension of the seed germination niche in fen wetlands. Plant Ecol 214: 489-499.

Fernández-Pascual E, Seal C, Pritchard HW (2015) Simulating the germination response to diurnally alternating temperatures under climate change scenarios: comparative studies on Carex diandra seeds. Ann Bot 115: 201-209.

Geiger R, Aron RH, Todhunter P (2009) The Climate Near the Ground. Rowman \& Littlefield, Lanham.

Gottfried M, Pauli H, Futschik A, Akhalkatsi M, Barancok P, Benito Alonso JL et al (2012) Continent-wide response of mountain vegetation to climate change. Nature Climate Change 2:111-115.

Gremer JR, Crone EE, Lesica P (2012) Are dormant plants hedging their bets? Demographic consequences of prolonged dormancy in variable environments. The American Naturalist 179: 315-327.

Grootjans AP, Adema EB, Bleuten W, Joosten H, Madaras M, Janáková M (2006) Hydrological landscape settings of base-rich fen mires and fen meadows: an overview. Applied Vegetation Science 9: 175-184.

Hájek M, Hájková P, Apostolova I (2008) New plant associations from Bulgarian mires. Phytologia Balcanica 14: 377-399.

Hájek M, Hájková P, Apostolova I, Horsák M, Plášek V, Shaw B et al (2009) Disjunct occurrences of plant species in the refugial mires of Bulgaria. Folia Geobotanica 44: 365-386.

Hájek M, Horsák M, Hájková P, Díte D (2006) Habitat diversity of Central European fens in relation to environmental gradients and an effort to standardise fen terminology in ecological studies. Perspect Plant Ecol Evol Syst 8: 97-114.

Hájek M, Horsák M, Tichý L, Hájková P, Dítě D, Jamrichová E (2011) Testing a relict distributional pattern of fen plant and terrestrial snail species at the Holocene scale: a null model approach. J Biogeogr 38: 742-755.

Hájková P, Jamrichová E, Horsák M, Hájek M (2013) Holocene history of a Cladium mariscus-dominated calcareous fen in Slovakia: vegetation stability and landscape development. Preslia 85: 289315 .

Hijmans RJ, Cameron SE, Parra JL, Jones PG, Jarvis A (2005) Very high resolution interpolated climate surfaces for global land areas. International Journal of Climatology 25: 1965-1978.

Hoyle GL, Venn SE, Steadman KJ, Good RB, McAuliffe EJ, Williams ER et al (2013) Soil warming increases plant species richness but decreases germination from the alpine soil seed bank. Global Change Biol 19: 1549-1561

Jamrichová E, Hájková P, Horsák M, Rybníčková E, Lacina A, Hájek M (2014) Landscape history, calcareous fen development and historical events in the Slovak Eastern Carpathians. Vegetation History and Archaeobotany 23: 497-513.
Jiménez-Alfaro B, Fernández-Pascual E, Díaz González T, PérezHaase A, Ninot J (2012) Diversity of rich fen vegetation and related plant specialists in mountain refugia of the Iberian Peninsula. Folia Geobotanica 47: 403-419.

Jiménez-Alfaro B, Fernández Menéndez S, Bueno Sánchez Á, Fernández Prieto JA (2013) Vegetation and hydrogeology along the distribution range of Centaurium somedanum, an endemic plant of mountain calcareous springs. Alpine Botany 123: 31-39.

Jiménez-Alfaro B, Hájek M, Ejrnaes R, Rodwell J, Pawlikowski P, Weeda EJ et al (2014) Biogeographic patterns of base-rich fen vegetation across Europe. Applied Vegetation Science 17: $367-$ 380 .

Klimesova J, Janecek S, Hornik J, Dolezal J (2011) Effect of the method of assessing and weighting abundance on the interpretation of the relationship between plant clonal traits and meadow management. Preslia 83: 437-453.

Körner C (2003) Alpine Plant Life: Functional Plant Ecology of High Mountain Ecosystems. Springer, Berlin Heidelberg New York.

Körner C, Paulsen J (2004) A world-wide study of high altitude treeline temperatures. J Biogeogr 31: 713-732.

Lapshina E (2004) Флора болот юго-востока западной сибири (Mire flora of the south-east of the West Siberia). University of Tomsk, Tomsk.

Leck MA, Schütz W (2005) Regeneration of Cyperaceae, with particular reference to seed ecology and seed banks. Perspect Plant Ecol Evol Syst 7: 95-133.

Luna B, Moreno JM (2012) Range-size, local abundance and germination niche-breadth in Mediterranean plants of two lifeforms. Plant Ecol 210: 85-95.

Marques AR, Atman AP, Silveira FA, de Lemos-Filho JP (2014) Are seed germination and ecological breadth associated? Testing the regeneration niche hypothesis with bromeliads in a heterogeneous neotropical montane vegetation. Plant Ecol 215: 517-529.

McKenzie JM, Siegel DI, Rosenberry DO, Glaser PH, Voss CI (2007) Heat transport in the Red Lake Bog, Glacial Lake Agassiz Peatlands. Hydrological Processes 21: 369-378

Orrù M, Mattana E, Pritchard HW, Bacchetta G (2012) Thermal thresholds as predictors of seed dormancy release and germination timing: altitude-related risks from climate warming for the wild grapevine Vitis vinifera subsp. sylvestris. Ann Bot 110: 16511660.

Outcalt SI, Nelson FE, Hinkel KM (1990) The zero-curtain effect: heat and mass transfer across an isothermal region in freezing soil. Water Resources Research 26: 1509-1516.

Parish F, Sirin A, Charman D, Joosten H, Minayeva T, Silvius M et al (2008) Assessment on Peatlands, Biodiversity and Climate Change: Main Report. Kuala Lumpur - Wageningen: Global Environment Centre - Wetlands International.

Pauli H, Gottfried M, Dullinger S, Abdaladze O, Akhalkatsi M, Benito Alonso JL et al (2012) Recent plant diversity changes on Europe's mountain summits. Science 336: 353-355.

Schütz W (2000) Ecology of seed dormancy and germination in sedges (Carex). Perspect Plant Ecol Evol Syst 3: 67-89.

Topić J, Stančić Z (2006) Extinction of fen and bog plants and their habitats in Croatia. Biodivers Conserv 15: 3371-3381.

Walck JL, Hidayati SN, Dixon KW, Thompson K, Poschlod P (2011) Climate change and plant regeneration from seed. Global Change Biol 17: 2145-2161. 
Table 1 Description of the study sites. The temperature limits for each site $(\mathrm{Wmin}=$ average of the winter minimums, Smax = average of the summer maximums) are given as calculated from the dataloggers (DL) and WorldClim (WC).

\begin{tabular}{|c|c|c|c|c|c|c|c|}
\hline \multirow{2}{*}{ Region } & \multirow{2}{*}{ Site } & \multirow{2}{*}{ Coordinates } & \multirow{2}{*}{ Altitude (m) } & \multicolumn{2}{|c|}{$\mathrm{W}_{\min }\left({ }^{\circ} \mathrm{C}\right)$} & \multicolumn{2}{|c|}{$\mathrm{S}_{\max }\left({ }^{\circ} \mathrm{C}\right)$} \\
\hline & & & & $\mathrm{DL}$ & $\mathrm{WC}$ & $\mathrm{DL}$ & $\mathrm{WC}$ \\
\hline \multirow[t]{3}{*}{ Spain (ES) } & Low & $43^{\circ} 07^{\prime} 09^{\prime \prime} \mathrm{N} 06^{\circ} 15^{\prime} 10^{\prime \prime} \mathrm{W}$ & 710 & 7.1 & 1.1 & 18.4 & 23.5 \\
\hline & Middle & $43^{\circ} 01^{\prime} 28^{\prime \prime} \mathrm{N} 06^{\circ} 12^{\prime} 37^{\prime \prime} \mathrm{W}$ & 1530 & 3.6 & -2.9 & 18.3 & 20.3 \\
\hline & High & $43^{\circ} 00^{\prime} 38^{\prime \prime} \mathrm{N} 05^{\circ} 56^{\prime} 49^{\prime \prime} \mathrm{W}$ & 1860 & 2.3 & -4.6 & 14.0 & 18.7 \\
\hline \multirow[t]{3}{*}{ Slovakia (SK) } & Low & $49^{\circ} 08^{\prime} 51^{\prime \prime N} 19^{\circ} 09^{\prime} 35^{\prime \prime E}$ & 440 & 1.3 & -6.4 & 21.8 & 22.7 \\
\hline & Middle & $48^{\circ} 56^{\prime} 22^{\prime \prime N} 19^{\circ} 19^{\prime} 23^{\prime \prime E}$ & 890 & 0.4 & -7.3 & 20.2 & 21.0 \\
\hline & High & $49^{\circ} 16^{\prime} 57^{\prime \prime N} 19^{\circ} 17^{\prime} 02^{\prime \prime E}$ & 1310 & 1.1 & -9.1 & 10.9 & 15.9 \\
\hline
\end{tabular}

Table 2 Results of the germination experiments. Germination percentages per collection of fresh and cold-stratified seeds after four weeks of incubation under three germination thermoperiods. The percentages are the average \pm SE of four dishes. GNB is the germination niche breadth of the collections calculated from the germination results using Pielou's evenness index.

\begin{tabular}{|c|c|c|c|c|c|c|c|c|}
\hline \multirow{2}{*}{ Species } & \multirow{2}{*}{ Site } & \multicolumn{3}{|c|}{ Fresh seeds } & \multicolumn{3}{|c|}{ Cold-stratified seeds } & \multirow{2}{*}{ GNB } \\
\hline & & $14 / 4$ & $22 / 12$ & $30 / 20$ & $14 / 4$ & $22 / 12$ & $30 / 20$ & \\
\hline \multirow[t]{5}{*}{ B. compressus } & SK High & 0 & 0 & $22 \pm 08$ & 0 & $36 \pm 13$ & $83 \pm 06$ & 0.53 \\
\hline & SK Middle & 0 & $05 \pm 03$ & $83 \pm 10$ & 0 & $08 \pm 08$ & $92 \pm 05$ & 0.53 \\
\hline & SK Low & 0 & 0 & $64 \pm 22$ & 0 & $08 \pm 08$ & $91 \pm 05$ & 0.47 \\
\hline & ES Middle & 0 & $11 \pm 11$ & 100 & 0 & $68 \pm 04$ & 100 & 0.67 \\
\hline & ES Low & 0 & $03 \pm 03$ & $82 \pm 03$ & 0 & $42 \pm 17$ & 100 & 0.61 \\
\hline \multirow[t]{4}{*}{ C. davalliana } & SK Middle & 0 & 0 & $16 \pm 04$ & $04 \pm 02$ & $29 \pm 10$ & $42 \pm 06$ & 0.65 \\
\hline & SK Low & 0 & 0 & $21 \pm 07$ & $10 \pm 10$ & $44 \pm 10$ & $62 \pm 04$ & 0.67 \\
\hline & ES High & 0 & 0 & $15 \pm 01$ & $30 \pm 05$ & $89 \pm 02$ & $72 \pm 04$ & 0.67 \\
\hline & ES Middle & 0 & 0 & $56 \pm 05$ & $27 \pm 07$ & $80 \pm 05$ & $90 \pm 02$ & 0.73 \\
\hline \multirow[t]{3}{*}{ C. echinata } & SK High & 0 & $91 \pm 03$ & $96 \pm 02$ & $97 \pm 01$ & 100 & $97 \pm 02$ & 0.90 \\
\hline & SK Middle & 0 & $40 \pm 11$ & $59 \pm 03$ & $17 \pm 08$ & $26 \pm 05$ & $49 \pm 12$ & 0.85 \\
\hline & ES High & 0 & $71 \pm 06$ & $28 \pm 03$ & 100 & 100 & $90 \pm 05$ & 0.86 \\
\hline \multirow[t]{5}{*}{ C. lepidocarpa } & SK Middle & 0 & 0 & $06 \pm 03$ & 0 & $16 \pm 06$ & $51 \pm 05$ & 0.44 \\
\hline & SK Low & 0 & 0 & 0 & 0 & $04 \pm 04$ & $26 \pm 11$ & 0.22 \\
\hline & ES High & 0 & 0 & $01 \pm 01$ & 0 & $03 \pm 02$ & $12 \pm 03$ & 0.39 \\
\hline & ES Middle & 0 & 0 & $08 \pm 05$ & $01 \pm 01$ & $19 \pm 06$ & $38 \pm 07$ & 0.56 \\
\hline & ES Low & 0 & 0 & $16 \pm 07$ & 0 & $32 \pm 06$ & $57 \pm 09$ & 0.55 \\
\hline \multirow[t]{4}{*}{ E. latifolium } & SK High & 0 & $06 \pm 03$ & $17 \pm 04$ & $11 \pm 02$ & $57 \pm 03$ & $39 \pm 09$ & 0.75 \\
\hline & SK Middle & 0 & $07 \pm 02$ & $39 \pm 02$ & $07 \pm 02$ & $89 \pm 03$ & $71 \pm 04$ & 0.71 \\
\hline & SK Low & 0 & $25 \pm 01$ & $73 \pm 08$ & $16 \pm 05$ & $96 \pm 01$ & $98 \pm 02$ & 0.80 \\
\hline & ES Middle & 0 & $20 \pm 04$ & $63 \pm 03$ & $28 \pm 07$ & $71 \pm 06$ & $72 \pm 06$ & 0.84 \\
\hline
\end{tabular}




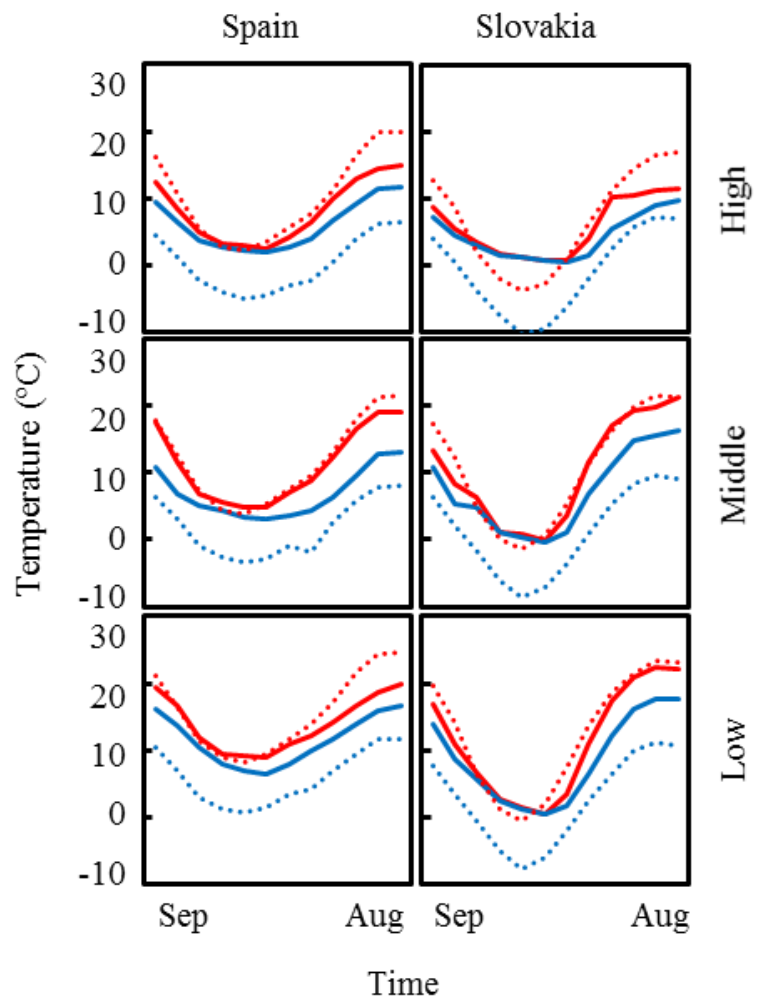

Fig. 1 Soil temperatures at each site from September to August. The solid lines are the monthly averages of the maximum and minimum daily temperatures as recorded from 2010 to 2013 by the dataloggers (except for the middle Slovakian site, only 2010-11). The dashed lines are the WorldClim predicted values (Colour only for the Web)

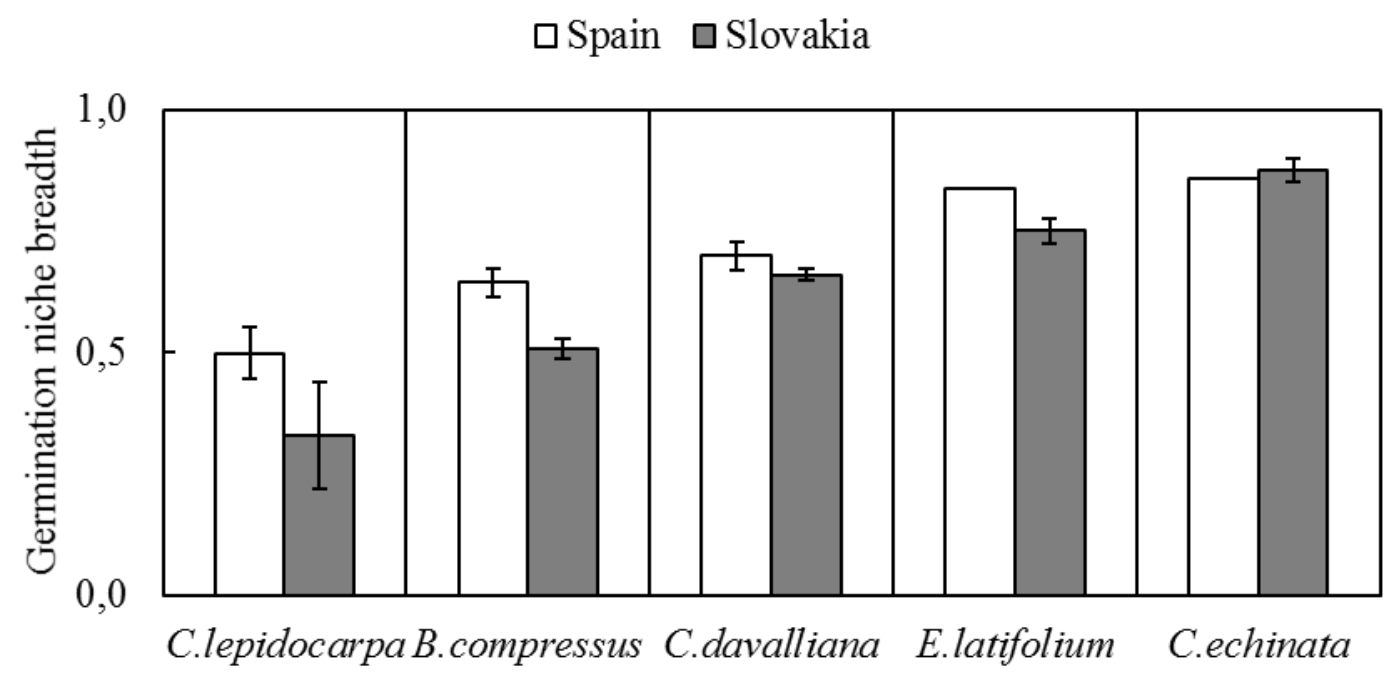

Fig. 2 Germination niche breadth (GNB) with respect to temperature per species and region. Each bar represents the average GNB \pm SE of a species in a region (white bars $=$ Spain, grey = Slovakia) 


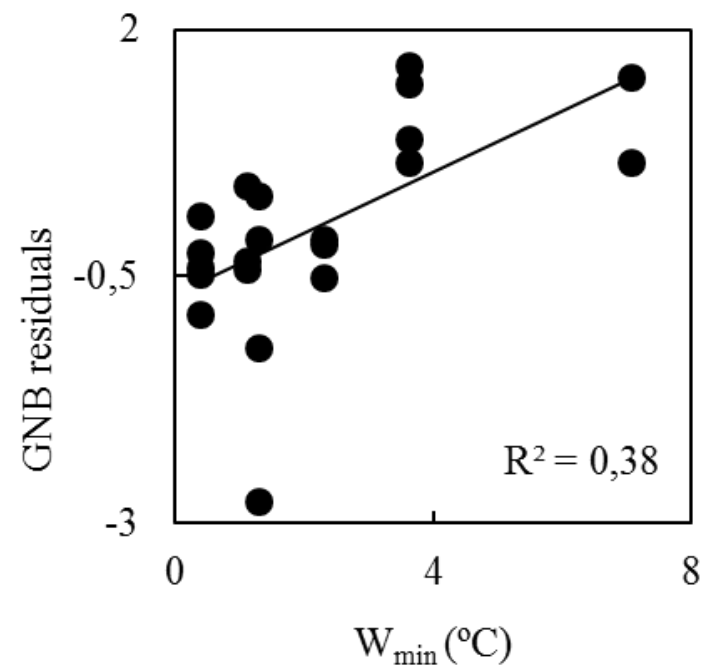

Fig. 3 Linear regression between the residuals of the germination niche breadth (GNB) and the average of the winter minimum temperatures (Wmin) calculated from soil dataloggers. Second axis represents the studentized residuals of a Linear Mixed-Effect Model fitted to the GNB with species as a random factor, to rule out the effect of the species. Each black dot is the residual of a collection 